needs of ethnic minorities will, we hope, support the committee's report with adequate resources. ${ }^{17}$

ALLISON STREETLY

Senior registrar in public health medicine

Department of Public Health Medicine,

United Medical and Dental Schools,

St Thomas's Hospital,

London SE1 7EH

MOIRA DICK

Consultant community paediatrician

West Lambeth Community Care NHS Trust

London SW9 9NU

MARK LAYTON

Senior lecturer

Department of Haematological Medicine

King's College Hospital,

London, SE5 9RS

1 World Health Organisation Regional Office for Europe. The haemoglobinopathies in Europe: combined report of two meetings. Copenhagen: WHO Regional Office for Europe, 1988

2 Streetly A. Health care needs for sickle cell disease in West Lambeth district. London: Faculty of Public Health Medicine, 1992. (Part II submission for Diploma of Membership of the Faculty of Public Health Medicine.
3 Gray A, Aninowu, Davies SC, Brozovic M. Mortality in sickle cell disease: the experience of a British centre. 7 Clin Pathol 1991:44:459-63.

Franklin IM. Services for sickle cell disease: unified approach needed. BM7 1988;296:592.

5 Department of Health and Social Security. Screening and counselling for sickle cell and thalassaemic diseases. London: DHSS, 1988. (EL (88)P92.)

6 Gaston MH, Verter JI, Woods G, Pegelow C, Kelleher J, Presbury G, et al. Prophylaxis with oral penicillin in children with sickle cell anaemia: a randomised trial. $N$ Engl f Med 1986;314: $1593-9$

Vichinsky E, Hurst D, Earles A, Kleman K, Lubin B. Newborn screening for sickle cell disease: effect on mortality. Pediatrics 1988;81:749-55.

8 Prashar U, Aninowu E, Brozovic M. Sickle cell anaemia - who cares? A survey of screening and counselling facilities in England. London: Runnymede Trust, 1985.

9 Smith I, Cook B, Beasley M. Review of neonatal screening programme for phenylketonuria. BMF 1991;303:333-5.

10 Tsevat J, Wong JB, Pauker SG, Steinberg MH. Neonatal screening for sickle cell disease: a cost-effectiveness analysis. F Pediatr 1991;118:546-54.

11 Lane PA, Eckman JR. Cost-effectiveness of neonatal screening for sickle cell disease. $\mathcal{J}$ Pediatr 1992;120:162-3.

12 Horn MEC, Dick MC, Frost B, Davis LR, Bellingham AJ, Stroud CE, et al. Neonatal screening for sickle cell disease in Camberwell: results and recommendations for a two year pilot study. $B M F$ 1986;292:737-40.

13 Milne RIG. Assessment of care of children with sickle cell disease: implications for neonatal screening programmes. BM7 1990;300:371-3.

14 Smith R. Using a mock trial to make a difficult clinical decision. $B M \mathcal{F} 1992 ; 305: 1284-7$.

15 Davies SC. The vaso-occlusive crisis of sickle cell disease, $B M \mathcal{F}$ 1991:302:1551-2.

16 Sergeant GR. Sickle cell disease. 2nd ed. Oxford: Oxford University Press, 1992.

16 Sergeant GR. Sickle cell disease. 2nd ed. Oxford: Oxford University Press, 1992. London: DoH, 1991. (Press release H91/627.)

\title{
At last a strategy for British science
}

\section{A lost opportunity}

Margaret Thatcher was deeply unpopular in the scientific community. The first prime minister for decades to hold a science degree, she provided no leadership for science, squeezed its funding at a time when remarkable new scientific vistas were opening up, and allowed Britain to slip towards the second division of science. When John Major took over and gave a cabinet minister, William Waldegrave, responsibility for science the expectations of scientists were raised. They were raised still further when $\mathrm{Mr}$ Waldegrave promised a fundamental review of science strategy. At last Britain was going to get serious about science.

Against this background, the publication of the strategy ${ }^{1}$ last week was a great disappointment (p 1498). ${ }^{2}$ There is no feeling of vision, leadership, passion, or commitment; no mechanism for handing real power to the scientists themselves; and no clear sense of how British science will move forward. It consists mainly of a rearranging of committees that are remote from the scientists.

What's wrong with British science? The diagnosis of the white paper seems about right: the British are good at science but poor at benefiting from the results; government objectives for science are unclear and sometimes contradictory; the broader culture doesn't value science, and much of the population, including most politicians and senior civil servants are woefully ignorant of science; the management of science is poor; and the career structure of scientists is a mess. The white paper might have added that government commitment to science seems ambivalent; that science is underfunded; and that too much of Britain's spending on science is on defence research.

Britain's first requirement is for a government completely committed to science, with a clear vision of what it wants from science. The white paper contains some of the rhetoric, but there is still no cabinet minister who concentrates on science alone. Mr Waldegrave is also reforming the civil service and implementing the citizen's charter, and on the day that his grand strategy for science was published media attention was focused more on whether he would be removed from the government than on his white paper. Then, there is no promise of more money, no attack on the waste of defence research, and no real incentive for industry to invest more in research and development.

Nor is it easy to see how the rearrangement of the central committees will improve the management of science. The Advisory Council on Science and Technology is to be changed to the Council for Science and Technology. The Advisory Board for the Research Councils, a quasiindependent body that was largely ignored anyway, will be absorbed into the Office of Science and Technology within $\mathrm{Mr}$ Waldegrave's department, and a new post of director general of research councils will be created. These changes suggest less independence and more direction.

The Science and Engineering Council is to be split into two councils, and the Agricultural and Food Research Council is to be changed to the Biotechnology and Biological Sciences Research Council. The research councils are all to be given a mission statement that makes explicit their commitment to wealth creation and quality of life. In future they will have a part time chairperson, a full time chief executive, and a slimmed down council.

For the Medical Research Council, this essentially amounts to business as usual, and it's hard to see that these changes at the top of the science pyramid will make much difference at all. The white paper quotes Sir Michael Atiyah, president of the Royal Society, that "too much stress on organisational structures may obscure the basic fact that progress in science depends on the ideas, inspiration, and dedication of individual scientists, not the machinations of councils, committees, and departments"-and then it seems largely to ignore his message. Nor does the white paper pay any attention to the management within the councils despite evidence that it may be outdated and top heavy. The $B M \mathcal{F}$ will return to this theme in a fortnight's time.

Every white paper must have some new rabbit to pull out of the hat, and the rabbit in this one is technology foresight. This is a process, highly developed in Japan, of systematically collecting the opinions of researchers, industrialists, and others on what science might produce and the market might need. Areas of science and technology ripe for development are thus identified, and the information is used to direct 
research. Technology foresight seems to have had far reaching effects in Japan and Germany, and such a system in Britain might provide a mechanism for moving research and development up a gear.

The white paper contains little new on science education in schools and undergraduate science, but it does propose encouraging graduates who are thinking of embarking on a career in science to begin with a masters degree rather than a PhD. This seems a good if limited idea, but there are few new ideas on developing the career structure for scientists or on increasing the importance of science in British society.

Maybe British science will develop despite, rather than because of, this new strategy, but it's ominous that the first general review of science in 20 years could produce nothing better.

RICHARD SMITH

Editor

$B M F$, London WC1H 9JR

1 Chancellor of the Duchy of Lancaster. Realising our potential: a strategy for science, engineering and technology. London: HMSO, 1993. (Cm 2250.)

2 Smith R. British government launches science strategy. BMF 1993;306:1498-9.

\section{NSAIDs and postoperative pain}

\section{Sooner is better than later}

Non-steroidal anti-inflammatory drugs (NSAIDs) have traditionally been used to relieve pain after minor surgery or have been prescribed two or three days after major surgery when the more powerful analgesic drugs have been withdrawn. Recent clinical studies have shown that in the setting of major surgery starting these drugs earlier is preferable, not instead of opioids but in addition to them. Moreover, the quality of analgesia from these combinations is better than that achieved by opioids alone.

Surgery or other trauma disrupts cellular integrity, and cell contents are released into the surrounding tissues. Some cellular components - such as serotonin, histamine, and bradykinin-directly stimulate nociceptors, causing afferent neuronal transmission that is interpreted in the brain as pain. Other compounds - such as the prostaglandins $\mathrm{E}_{2}$ and $\mathrm{I}_{2}-$ do not cause pain directly but cause hyperalgesia by increasing the sensitivity of the nerve endings to the effects of pain producing substances. Increased sensitivity to painful stimuli extends to areas not directly involved in the initial trauma, probably by antidromic axo-axonal stimulation and by dorsal horn cell sensitisation. ${ }^{12}$ Preventing or inhibiting this sensitisation of peripheral nerve endings would therefore limit the transmission of noxious stimuli to the spinal cord and thus reduce the need for centrally acting analgesics.

Damage to cell membranes activates the synthesis of prostaglandin from arachidonic acid. Non-steroidal antiinflammatory drugs act mainly by inhibiting this pathway; by preventing the synthesis of prostaglandin they reduce the sensitivity of the nerve endings to painful stimuli and thus relieve pain.

Studies in patients after major abdominal or thoracic surgery have consistently shown that non-steroidal antiinflammatory drugs given soon after operation reduce the requirements for opioids by about a third in the first or second postoperative day. This occurred for ketorolac ${ }^{3}$ and diclofenac $^{4}$ given intramuscularly and indomethacin ${ }^{5}$ and ibuprofen $^{6}$ given as rectal suppositories. Surprisingly, starting these drugs preoperatively is no better than starting them postoperatively, although this has been the subject of only one published study. ${ }^{7}$

Where intravenous opioids were titrated according to pain patients receiving non-steroidal anti-inflammatory drugs tended to experience less pain..$^{3-5}$ This indicates that this combination provides better pain control than opioid alone. For severe pain, the efficacy of non-steroidal antiinflammatory drugs is limited, but these studies clearly suggest that opioids, when used alone, may also be inadequate and, like the anti-inflammatory drugs should be viewed as having a "ceiling" effect.
Some questions about the use of non-steroidal antiinflammatory drugs preoperatively remain unanswered. What is the risk of damage to the upper gastrointestinal tract? Peptic ulceration may undoubtedly follow chronic ingestion of these drugs, but no information is available regarding acute short term use. Should these patients receive prophylactic $\mathrm{H}_{2}$-receptor antagonists at the same time? Extrapolating the results of studies evaluating prophylaxis in chronic users of non-steroidal anti-inflammatory drugs does not support such a proposal. ${ }^{8}$

Are these drugs safe in patients with renal impairment, cardiac failure, or asthma? As with drug prescribing in general, the answer comes down to balancing the risks against the benefits for each patient. In most cases, the benefits of reducing an elderly patient's opioid requirement by a third will outweigh any short term reduction in renal function. At worst, these adverse effects rapidly reverse on stopping the drug.

Platelet dysfunction resulting from non-steroidal antiinflammatory drugs given preoperatively increases the risk of preoperative bleeding, but this does not seem clinically important. ${ }^{49}$ Any increase in blood loss may assume importance in some circumstances, however-such as after neurosurgery - and delaying administration of non-steroidal anti-inflammatory drugs until the postoperative period may be judicious.

Some orthopaedic surgeons have been concerned about delayed fracture healing in animals caused by non-steroidal anti-inflammatory drugs. ${ }^{10}$ Determining the relevance of these animal studies to the acute short term use of these drugs in humans requires further research.

Many compounds influence the sensitivity of the peripheral nociceptor apart from the prostaglandins, so non-steroidal anti-inflammatory drugs alone should not be expected to eliminate pain. The goal of postoperative pain management should be to prevent peripheral nociceptor stimulation and dorsal horn sensitisation. Reducing the sensitivity of the primary afferent nerve terminal to painful stimuli by using non-steroidal anti-inflammatory drugs is one useful early step.

DERMOT F MURPHY Consultant anaesthetist

Department of Anaesthesia,

Sir Charles Gairdner Hospital, Perth 6009, Australia

1 Raja SN, Meyer RA, Campbell JN. Peripheral mechanisms of somatic pain. Anesthesiology 1988;68:571-90.

2 Woolf CJ. Recent advances in the pathophysiology of acute pain. Br f Anaesth 1989;63:139-46. 